\title{
ДЕТОКСИКАЦІЙНІ Й АНТИОКСИДАНТНІ ВЛАСТИВОСТІ АМІНОКИСЛОТ У ЩУРІВ, ІНТОКСИКОВАНИХ НІТРИТОМ НАТРІЮ
}

Вступ. Зростаюче застосування азотних добрив є основним джерелом надходження нітратів і нітритів у навколишнє середовище. Нітрити в організмі тварин змінюють валентність заліза в гемоглобіні, перетворюючи його в метгемоглобін, який не здатен у легенях сполучатися з Оксигеном і перетворюватися в оксигемоглобін. Відповідно, втрачається основна фрункція гемоглобіну - зворотно зв'язувати Оксиген та доставляти його до тканин, внаслідок цього розвивається гіпоксія. Нітрати і нітрити $\epsilon$ антиспазматичними отрутами. Деструктивний вплив нітратів і нітритів на організм зумовлений ініціацією вільнорадикальних процесів, що призводить до порушення клітинних мембран, зниження активності імунної системи.

Мета дослідження - вивчити вплив амінокислот на окремі показники антиоксидантної системи щурів за дії нітриту натрію.

Методи дослідження. Дослідження проводили на лабораторних білих щурах-самцях, яким внутрішньочеревно вводили нітрит натрію та додатково глутамінову кислоту і цистеїн. Тваринам згодовували стандартний комбікорм для лабораторних щурів. Їх утримували в клітках за стандартних лабораторних умов з 12-годинним циклом світла/12-годинним циклом темряви. Усі щури мали вільний доступ до стандартної дієти гризунів і води ad libitum. В еритроцитах крові визначали вміст відновленого глутатіону та ряд ензимів антиоксидантного захисту.

Результати й обговорення. Встановлено, що застосування нітриту натрію призводило до змін окремих показників системи антиоксидантного захисту. Досліджуваний токсикант викликав зниження вмісту відновленого глутатіону, активності глутатіонпероксидази і каталази в еритроцитах крові щурів. У тварин дослідних груп, які після досліджуваного ксенобіотика додатково отримували глутамінову кислоту і цистеїн, спостерігали менш помітні зміни порівняно з контрольною групою щурів.

Висновки. Досліджуваний токсикант призводив до зниження вмісту відновленого глутатіону, активності глутатіонпероксидази і каталази в еритроцитах крові щурів. Менш помітні зміни було зафріксовано у тварин дослідних груп, які додатково отримували досліджувані амінокислоти. цити.

КЛЮЧОВІ СЛОВА: амінокислоти; антиоксидантна система; кров; ензими; нітрит натрію; еритро-

ВСТУП. Хімізація промисловості є причиною зростання дії різних хімічних фракторів на організм людини і тварин. Це зумовлено значним забрудненням навколишнього середовища різними токсикантами, збільшенням вмісту нітратів і нітритів у продуктах харчування. Дані чинники проявляють негативний вплив на обмін речовин та фрізіологічні фрункції в організмі людини і тварин. Найбільша ж небезпека підвищеного вмісту нітратів в організмі полягає в тому, що нітрати і нітрити в результаті біохімічних процесів переходять у N-нітрозосполуки, мають мутагенну дію $[1,2]$. Особливо чутливі до дії нітратів і нітритів тварини раннього віку. В патогенезі інтоксикації нітритами особливу роль відіграють вільнорадикальні процеси [3-6]. Основним джерелом над(с) Н. О. Салига, 2020. ходження нітратів і нітритів у навколишнє середовище $є$ зростаюче застосування азотних добрив, спалення побутових відходів, що спричиняє забруднення повітря, ґрунту, водойм та ін.

Беручи до уваги вищесказане, метою цього дослідження було вивчити вплив амінокислот на окремі показники антиоксидантної системи щурів за дії нітриту натрію.

МЕТОДИ ДОСЛІДЖЕННЯ. Дослідження проведено на білих щурах-самцях масою 200-220 г. Під час виконання досліджень на тваринах дотримувалися принципів біоетики, законодавчих норм і вимог згідно з положенням Європейської конвенції про захист хребетних тварин, що використовуються для дослідних та інших наукових цілей (Страсбург, 1986) і Загальних етичних 
принципів експериментів на тваринах, ухвалених на Першому національному конгресі з біоетики (Київ, 2001). Було сформовано 4 групи тваринаналогів (3 дослідних і 1 контрольну). Тваринам 1-ї дослідної групи (Д1) вводили внутрішньочеревно одноразово нітрит натрію з розрахунку 50 мг/кг; тваринам 2-ї дослідної групи (Д2) - нітрит натрію з розрахунку 50 мг/кг, після чого розчин глутамінової кислоти в дозі 750 мг/кг; тваринам 3-ї дослідної групи (Д3) - нітрит натрію з розрахунку 50 мг/кг, після чого розчин глутамінової кислоти в дозі 750 мг/кг та розчин цистеїну в дозі $300 \mathrm{мг/кг;} \mathrm{щурам} \mathrm{контрольної} \mathrm{групи} \mathrm{(К)} \mathrm{-}$ відповідну кількість фрізрозчину. Через добу тварин усіх груп за анестезії ефріром декапітували. В еритроцитах крові визначали активність супероксиддисмутази (КФ 1.15.1.1), каталази (КФ 1.11.1.6), глутатіонпероксидази (КФ 1.11.1.9), глутатіонредуктази (КФ 1.6.4.2), вміст відновленого глутатіону [7]. Одержані цифрові дані обробляли статистично.

РЕЗУЛЬТАТИ Й ОБГОВОРЕННЯ. ЧУТЛИВОЮ до дії ксенобіотиків $\epsilon$ антиоксидантна система. Дія ксенобіотиків викликає інтенсифрікацію процесів пероксидного окиснення ліпідів в організмі тварин та зниження активності системи антиоксидантного захисту. До ключових регуляторних систем організму тварин належить антиоксидантна система захисту, яка регулює в організмі рівень вільних радикалів та пероксидів, що утворюються під час біохімічних реакцій, з участю активних форм Оксигену. Інтенсифікація вільнорадикальних процесів $є$ універсальним механізмом ушкодження клітин. Результати наших досліджень показали, що за дії на організм тварин нітриту натрію значних змін зазнавала антиоксидантна система, зокрема такий її компонент, як відновлений глутатіон, вміст якого зменшувався майже у 2 рази в еритроцитах крові щурів 1-ї дослідної групи, яким вводили нітрит натрію без застосування амінокислот (рис. 1). У тварин 2-ї і 3-ї груп він не лише не знижувався, але й був незначно вищим порівняно $з$ контролем.

Важливим захисним ензимом, який бере участь у відновленні $\mathrm{H}_{2} \mathrm{O}_{2}$ до води, а органічних гідропероксидів - до гідросполук, є глутатіонпероксидаза. Результати наших досліджень показали (рис. 2), що її активність у тварин, які отримували нітрит натрію, вірогідно $(p<0,05)$ знижувалась стосовно контролю. На цьому фоні більш вагомо відзначалися дослідні групи щурів, які одержували вищевказані амінокислоти, а саме активність ензиму у тварин 2-ї і 3-ї дослідних груп майже виходила на рівень контрольних значень порівняно зі щурами контрольної групи.
Активність глутатіонредуктази в еритроцитах крові щурів дослідних груп не зазнавала вірогідних змін порівняно $з$ тваринами контрольної групи (рис. 3).

Супероксиддисмутаза відіграє важливу роль в інгібуванні процесів вільнорадикального окис-

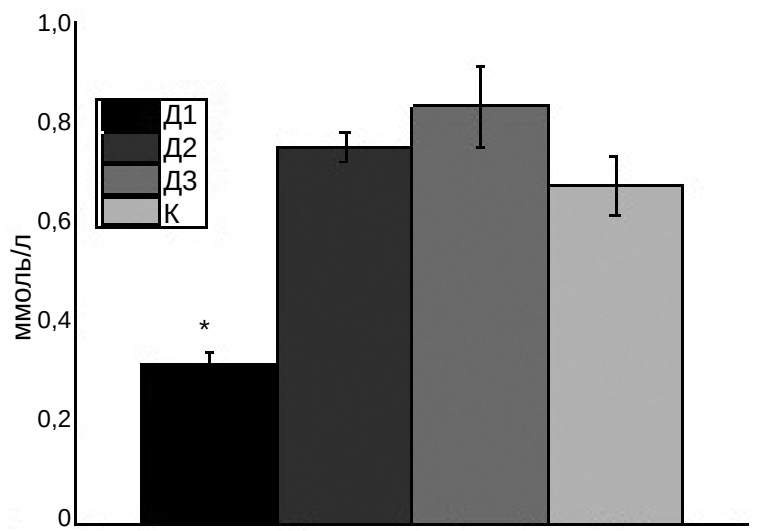

Рис. 1. Вміст відновленого глутатіону в крові щурів за дії нітриту натрію.

Примітка. Тут і на рисунках 2, 5: * - вірогідність відмінностей у значеннях показників між контрольною та дослідними групами тварин $(\mathrm{p}<0,05)$.

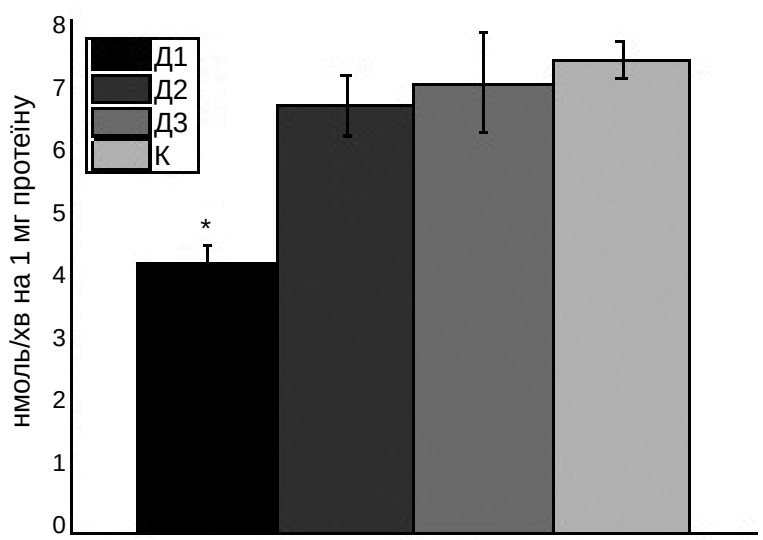

Рис. 2. Активність глутатіонпероксидази в еритроцитах крові щурів за дії нітриту натрію.

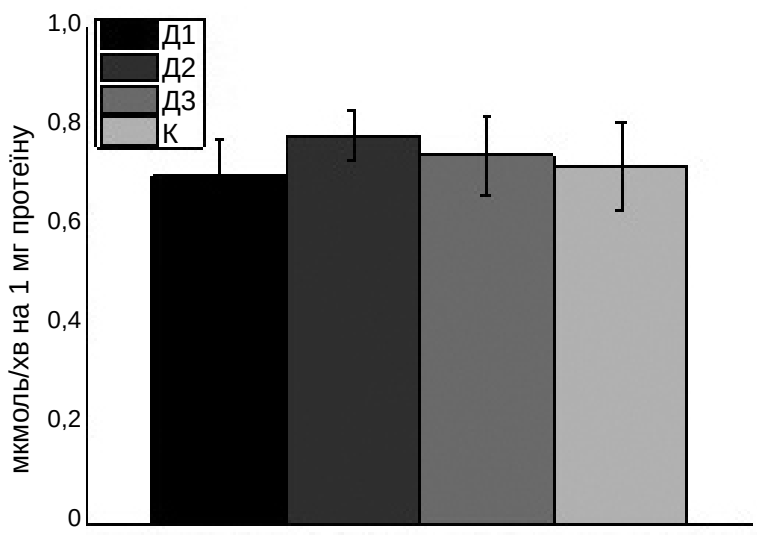

Рис. 3. Активність глутатіонредуктази в еритроцитах крові щурів за дії нітриту натрію. 
нення. Цей ензим забезпечує дисмутацію супероксидного радикала, що є попередником гідроксильного радикала. Слід зазначити, що активність супероксиддисмутази в еритроцитах крові щурів була на однаковому рівні у тварин усіх дослідних груп порівняно з контролем (рис. 4). Що стосується активності каталази, то вона вірогідно знижувалась: у щурів 1-ї дослідної групи - в 1,77 раза, у тварин 3-ї дослідної групи в 1,42 раза порівняно з контролем (рис. 5).

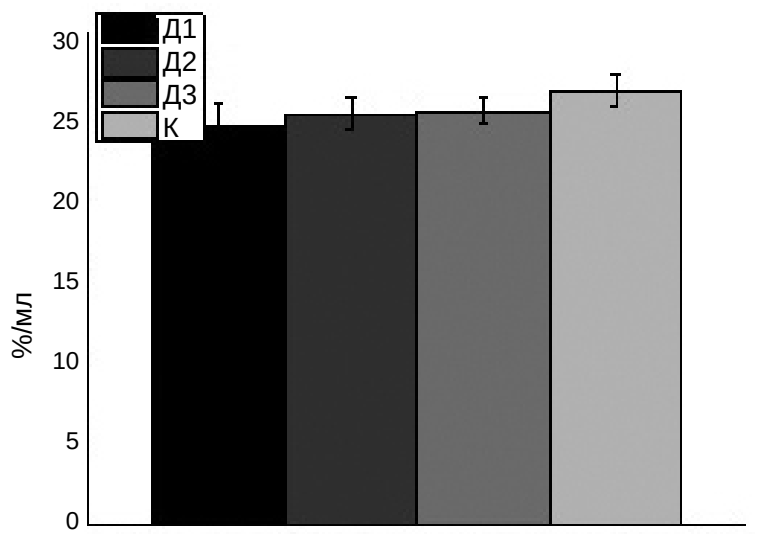

Рис. 4. Активність супероксиддисмутази в еритроцитах крові щурів за дії нітриту натрію.

ВИСНОВКИ. 1. Після застосування нітриту натрію спостерігали зниження активності антиоксидантних ензимів, зокрема глутатіонпероксидази і каталази, в еритроцитах крові та тканинах щурів порівняно з тваринами контрольної групи.

2. Використання глутамінової кислоти і глутамінової кислоти в комплексі з цистеїном після введення нітриту натрію призводило до зростан-
Метаболічні процеси, що відбуваються в організмі тварин за дії нітросполук, потребують великої кількості амінокислот [8, 9]. Глутамінова кислота сприяє нейтралізації шкідливої дії нітратів і нітритів, що потрапили в організм [10]. Введені амінокислоти можуть до певної міри знизити ступінь гіперкатаболізму, відновити показники протеїнового обміну та приводять до менш помітних змін показників антиоксидантної системи.

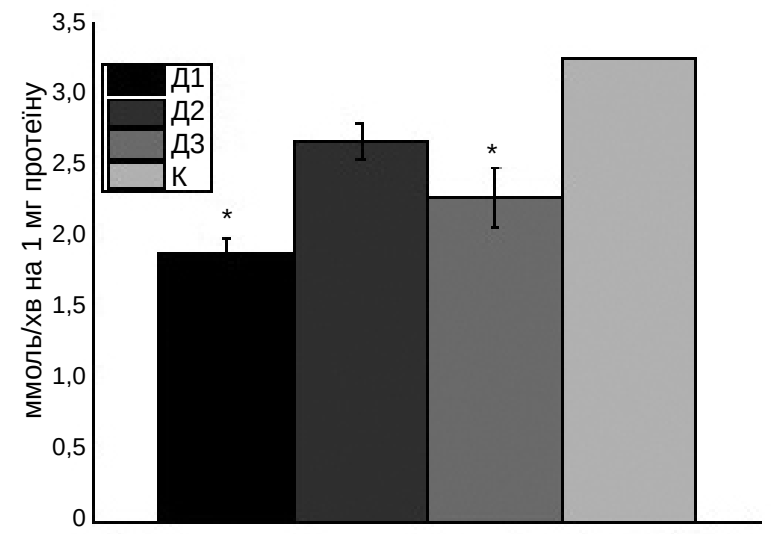

Рис. 5. Активність каталази в еритроцитах крові щурів за дії нітриту натрію.

ня вмісту відновленого глутатіону й активності ензимів антиоксидантного захисту в тканинах печінки та міокарда тварин дослідних груп стосовно контролю.

Перспективи подальших досліджень. Заплановано вивчити коригувальну дію амінокислот на показники антиоксидантної та імунної систем щурів, уражених ксенобіотиками.

\section{СПИСОК ЛІТЕРАТУРИ}

1. Ansari F. A. Protective effect of carnosine and $\mathrm{N}$-acetylcysteine against sodium nitrite-induced oxidative stress and DNA damage in rat intestine / F. A. Ansari, A. A. Khan, R. Mahmood // Environ. Sci. Pollut. ResInt. 2018. - 25 (20). - P. 19380-19392.

2. Karwowska M. Impact of sodium nitrite reduction on lipid oxidation and antioxidant properties of cooked meat products / M. Karwowska, A. Kononiuk, K. M. Wójciak // Antioxidants. - 2019. - 9 (9). - P. 1-15.

3. Acute oral dose of sodium nitrite causes redox imbalance and DNA damage in rat kidney / F. A. Ansari, S. N. Ali, A. A. Khan, R. Mahmood // J. Cell Biochem. 2018. - 119 (4). - P. 3744-3754.

4. Ansari F. A. Sodium nitrite-induced oxidative stress causes membrane damage, proteinoxidation, lipidperoxidation and alters major metabolic pathways in human erythrocytes / F. A. Ansari, S. N. Ali, R. Mahmood // Toxicol. InVitro. - 2015. - 29 (7). - P. 1878-1886.

5. Hepatoprotective effects of codliveroil against sodium nitrite toxicity in rats / M. F. Salama, A. Abbas,
M. M. Darweish [et al.] // J. Pharmaceutical Biology. 2019. - 51 (11). - P. 1435-1443.

6. Curcumin protects sodium nitrite-induced hepatotoxicity in Wistar rats / O. O. Adewale, E. S. Samuel, M. Manubolu, K. Pathakoti // Toxicol. Rep. - 2019. -6. P. 1006-1011.

7. Salyha N. O. Activity of the glutathione system of antioxidant defense in rats under the action of L-glutamic acid / N. O. Salyha // Ukr. Biochem. J. - 2013. - 85 (4). P. 40-47.

8. Brosnan J. T. Glutamate: a truly functional aminoacid / J. T. Brosnan, M. E. Brosnan // AminoAcids. 2012. - 25. - P. 207-218.

9. Hansen A. M. Glutamate joins the ranks of immunomodulators / A. M. Hansen, R. R. Caspi // Nature Medicine. - 2010. - 16, No. 8. - P. 856-858.

10. Aminoacid nutrition in animals: protein synthesis and beyond / G. Wu, F. W. Bazer, Z. Dai [et al.] // Annu. Rev. Anim. Biosci. - 2014. - 2. - P. 387-417. 


\section{REFERENCES}

1. Ansari, F.A., (2018). Protective effect of carnosine and $\mathrm{N}$-acetylcysteine against sodium nitrite-induced oxidative stress and DNA damage in rat intestine. Environ. Sci. Pollut. ResInt., 25 (20), 19380-19392.

2. Karwowska, M., Kononiuk, A., \& Wójciak, K.M. (2019). Impact of sodium nitrite reduction on lipid oxidation and antioxidant properties of cooked meat products. Antioxidants., 9 (9), 1-15.

3. Ansari, F.A. Khan, A.A., \& Mahmood, R. (2018). Acute oral dose of sodium nitrite causes redox imbalance and DNA damage in rat kidney. J. Cell Biochem., 19 (4), 3744-3754.

4. Ansari, F.A., Ali, S.N., \& Mahmood, R. (2015). Sodium nitrite-induced oxidative stress causes membrane damage, proteinoxidation, lipidperoxidation and alters major metabolic pathways in human erythrocytes. Toxicol. In Vitro, 29 (7), 1878-1886.
5. Salama, M.F., Abbas, A., Darweish, M.M., ElHawwary, A.A., \& Al-Gayyar, M.M. (2019). Hepatoprotective effects of codliveroil against sodium nitrite toxicity in rats. J. Pharmaceutical Biology, 51 (11), 1435-1443.

6. Adewale, O.O., Samuel, E.S., Manubolu, M., \& Pathakoti, K. (2019). Curcumin protects sodium nitriteinduced hepatotoxicity in Wistar rats. Toxicol. Rep., 6, 1006-1011.

7. Salyha, N.O. (2013). Activity of the glutathione system of antioxidant defense in rats under the action of L-glutamic acid. Ukr. Biochem. J., 85 (4), 40-47.

8. Brosnan, J.T., \& Brosnan, M.E. (2012). Glutamate: a truly functional aminoacid. AminoAcids, 25, 207-218.

9. Hansen, A.M., \& Caspi, R.R. (2010). Glutamate joins the ranks of immunomodulators. Nature Medicine, 16 (8), 856-858.

10. Wu, G., Bazer, F.W., Dai, Z., Li, D., Wang, J., \& $\mathrm{Wu}$, Z. (2014). Aminoacid nutrition in animals: protein synthesis and beyond. Annu. Rev. Anim. Biosci., 2, 387417.

\section{ДЕТОКСИКАЦИОННЫЕ И АНТИОКСИДАНТНЫЕ СВОЙСТВА АМИНОКИСЛОТ У КРЫС, ИНТОКСИЦИРОВАННЫХ НИТРИТОМ НАТРИЯ}

\section{Резюме}

Вступление. Растущее применение азотных удобрений является основным источником поступления нитратов и нитритов в окружающую среду. Нитриты в организме животных меняют валентность железа в гемоглобине, превращая его в метгемоглобин, который не способен в легких сочетаться с кислородом и превращаться в оксигемоглобин. Соответственно, теряется основная функция гемоглобина - обратно связывать кислород и доставлять его в ткани, вследствие этого развивается гипоксия. Нитраты и нитриты являются антиспазматическими ядами. Деструктивное влияние нитратов и нитритов на организм обусловлено инициацией свободнорадикальных процессов и перекисного окисления липидов, что приводит к нарушению клеточных мембран, снижению активности иммунной системы.

Цель исследования - изучить влияние аминокислот на отдельные показатели антиокидантной системы крыс при действии нитрита натрия.

Методы исследования. Исследования проводили на лабораторных белых крысах-самцах, которым внутрибрюшно вводили нитрит натрия и дополнительно глутаминовую кислоту и цистеин. Животным скармливали стандартный комбикорм для лабораторных крыс. Их удерживали в клетках в стандартных лабораторных условиях с 12-часовым циклом света/12-часовым циклом темноты. Все крысы имели свободный доступ к стандартной диете грызунов и воде ad libitum. В эритроцитах крови определяли содержание восстановленного глутатиона и ряд энзимов антиоксидантной защиты.

Результаты и обсуждение. Установлено, что применение нитрита натрия приводило к изменениям отдельных показателей системы антиоксидантной защиты. Исследуемый токсикант вызывал снижение содержания восстановленного глутатиона, активности глутатионпероксидазы и каталазы в эритроцитах крови крыс. У животных опытных групп, которые после исследуемого ксенобиотика дополнительно получали глутаминовую кислоту и цистеин, наблюдали менее заметные изменения по сравнению с контрольной группой крыс.

Выводы. Исследуемый токсикант приводил к снижению содержания восстановленного глутатиона, активности глутатионпероксидазы и каталазы в эритроцитах крови крыс. Менее заметные изменения были зафиксированы у животных, которые дополнительно получали исследуемые аминокислоты.

КЛЮЧЕВЫЕ СЛОВА: аминокислоты; антиоксидантная система; кровь; энзимы; нитрит натрия; эритроциты. 


\section{DETOXIFYING AND ANTIOXIDANT EFFECT OF AMINOACIDS IN RATS INTOXICATED WITH SODIUM NITRITE}

\section{Summary}

Introduction. The growing use of nitrogen fertilizers is a major source of nitrates and nitrites in the environment. Nitrites in animals change the valence of iron in hemoglobin, converting it to methemoglobin, which is unable to combine with oxygen in the lungs and be converted to oxyhemoglobin. Accordingly, the main function of hemoglobin is lost - to bind oxygen and deliver it to the tissues. As a result, hypoxia develops. Nitrates and nitrites are antispasmodic poisons. The destructive effect of nitrites and nitrates on the body is due to the initiation of free radical processes and lipid peroxidation, which leads to disruption of cell membranes, reduced activity of the immune system.

The aim of the study - to learn the effect of amino acids on individual indicators of the antioxidant system of rats under the action of sodium nitrite.

Research Methods. The studies were performed on laboratory white male rats injected intraperitoneally with sodium nitrite and additionally glutamic acid and cysteine. The animals were fed standard feed for laboratory rats. All rats had a free access to a standard rodent diet and water ad libitum. They were housed in cages under standard laboratory conditions with a 12-h light/12-h dark cycle. A number of antioxidant protection enzymes were determined in erythrocytes.

Results and Discussion. It was found that the use of sodium nitrite led to changes in indicators of the antioxidant defense system. The result ssuggest that the level of GSH and activity of glutathione peroxidase and catalase decreased in the red cells of animals. Animals of the experimental groups that received glutamic acid and cysteine after the sodium nitrite underwent less noticeable changes compared to the control.

Conclusions. The results suggest that the level of GSH and activity of glutathione peroxidase and catalase decreased in the red cells of animals. Less noticeable changes were found in animals that additionally received the studied amino acids.

KEY WORDS: aminoacids; antioxidant system; blood; enzymes; sodium nitrite; erythrocytes. 